\title{
Percutaneous mitral valve repair: the beginning of the end or the end of the beginning?
}

\section{Alec Vahanian*, Dominique Himbert, Eric Brochet and David Messika-Zeitoun}

Address: Hôpital Bichat, 46 rue Henri Huchard, 75018 Paris, France

*Corresponding author: Alec Vahanian (alec.vahanian@bch.aphp.fr)

fl000 Medicine Reports 2010, 2:2I (doi:10.3410/M2-2I)

The electronic version of this article is the complete one and can be found at: http://fl000.com/reports/medicine/content/2/2 I

\begin{abstract}
The new percutaneous mitral valve repair techniques are at an early stage. Preliminary series show that they are feasible; however, they need to be further evaluated in comparison with contemporary treatment to accurately assess their efficiency. Potential applications may benefit high-risk patients after thorough evaluation.
\end{abstract}

\section{Introduction and context}

Mitral regurgitation (MR) represents more than 30\% of native valve disease [1-3]. The good results of surgery, particularly valve repair, set a high standard for future percutaneous valve intervention [4-6]. However, in current practice worldwide, surgery is denied in many patients with severe valvular heart disease and symptoms [7] and mitral valve repair is not always used or feasible $[8,9]$. In addition, surgical risk remains high in a significant percentage of contemporary patients who are elderly and have comorbidities [3].

\section{Recent advances}

Two main techniques can be used for percutaneous mitral valve repair: the edge-to-edge technique and prosthetic ring annuloplasty. The edge-to-edge technique mimics the surgical Alfieri procedure, which creates a double mitral orifice by means of a few stitches securing the two leaflets together in their midpart [10]. This technique can be performed percutaneously using a clip (MitraClip ; Evalve, Inc., Menlo Park, CA, USA) made of cobalt-chromium alloy and covered with polyethylene terephthalate [11]. Another design involved the use of one or more sutures deployed via a catheter-based device. The technique requires general anaesthesia and a transseptal approach with continuous fluoroscopic and transoesophageal echographic guidance to catch the leaflets at their coaptation point [12] (Figure 1). These constraints mean that the technique is initially difficult to learn and will limit its dissemination.

Current clinical experience is focused almost exclusively on the clip technique (MitraClip) in 500 patients $[13,14]$ because the development of the other, suture-based device has been abandoned [15]. In the initial EVEREST (Endovascular Valve Edge-to-Edge Repair Study) registry including 107 patients, severe MR was of degenerative origin in around $80 \%$ of patients. Success rate and procedure time improved steadily with experience. Sixtyfour percent of patients were discharged from hospital with a clip and MR of less than grade 2/4, and the procedure did not induce mitral stenosis [14-17]. The procedure was well tolerated and 98\% were free from any complication in the expert centres involved in the study. After 36 months, $66 \%$ of patients who underwent a successful procedure were free from death, mitral valve surgery, and MR greater than grade 2/4 [14]. Preliminary studies also report satisfactory outcomes in patients at high risk or in functional MR subsets.

Limitations of the edge-to-edge technique can be anticipated: this technique, in isolation, does not address the problem of annulus dilatation, which has been shown to increase the risk of secondary residual 
Figure I. Percutaneous mitral valve repair: edge-to-edge technique using a clip (MitraClip; Evalve, Inc., Menlo Park, CA, USA)
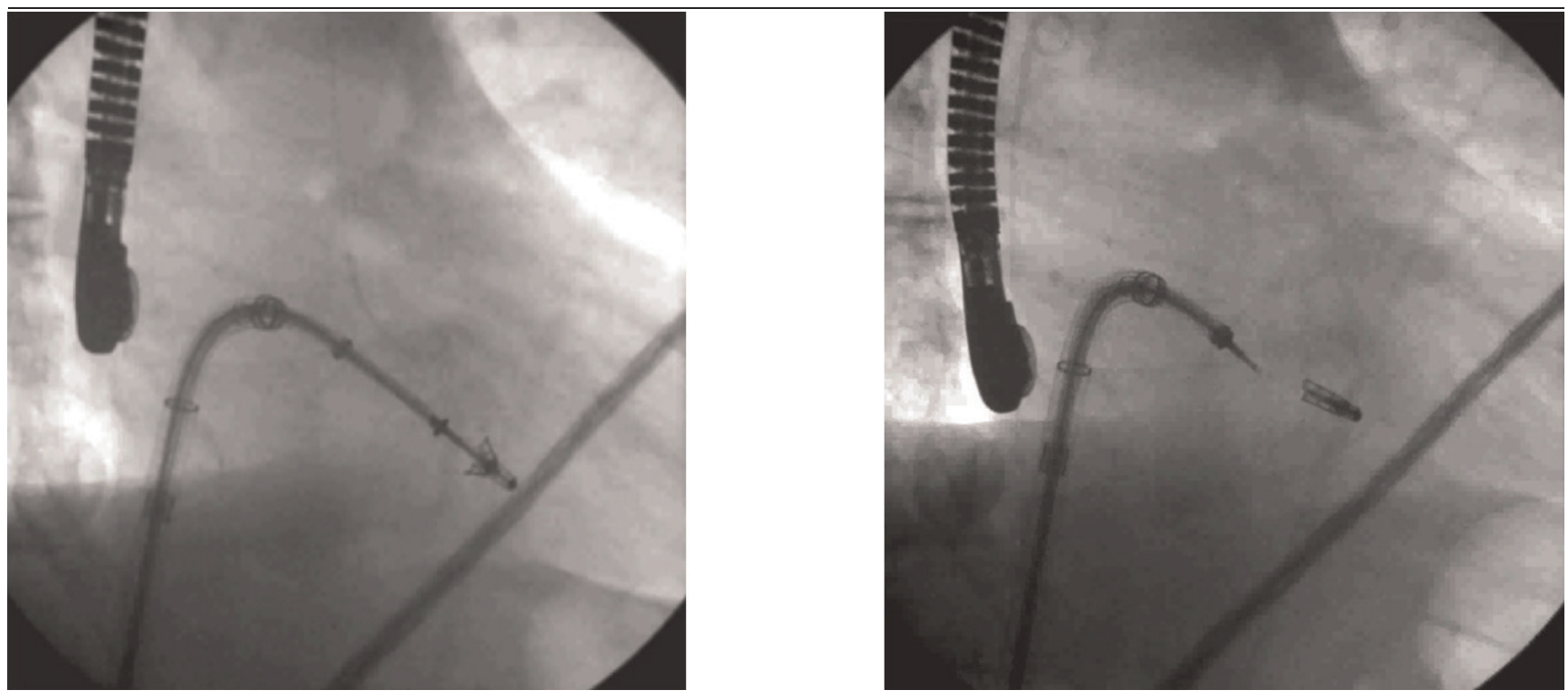

Left panel: Right anterior oblique view. The clip is opened in the left ventricle, just below the mitral valves under transoesophageal echocardiographic guidance. Right panel: Right anterior oblique view. The clip is closed at the coaptation point of the mitral valves and then released. Images courtesy of Peter Block.

regurgitation. In degenerative $M R$, its use will probably be restricted to a limited percentage of patients. Residual regurgitation carries the risk of insidious development of left ventricular dysfunction.

Prosthetic ring annuloplasty is key in most cases of surgical valve repair; data show that the diameter of the mitral annulus can be reduced by inserting a constraining device in the proximate coronary sinus [18]. Several devices are under investigation: the Carillon device (Cardiac Dimensions Inc., Kirkland, WA, USA) uses a nitinol wire with proximal and distal anchors [19]; the Viacor device (Viacor, Inc., Wilmington, MA, USA) leads to a decrease in anteroposterior diameter through the application of pressure on the midportion of the posterior leaflet by using several rigid elements placed in a plastic sleeve [20]. These two devices can be withdrawn if efficacy is not satisfactory or if the circumflex artery is compromised. In the Monarc device (Edwards Lifesciences LLC, Irvine, CA, USA), selfexpanding stents are joined via a bridge that contracts after 6 weeks [21]. All of these devices have had several technical modifications over time.

Prosthetic ring annuloplasty is easier to perform than the edge-to-edge technique and requires a catheterisation of the coronary sinus through the jugular vein and the delivery of the devices under fluoroscopic guidance (Figure 2).
Figure 2. Percutaneous mitral valve repair: edge-to-edge technique using a suture (Mobius; Edwards Lifesciences LLC, Irvine, CA, USA)

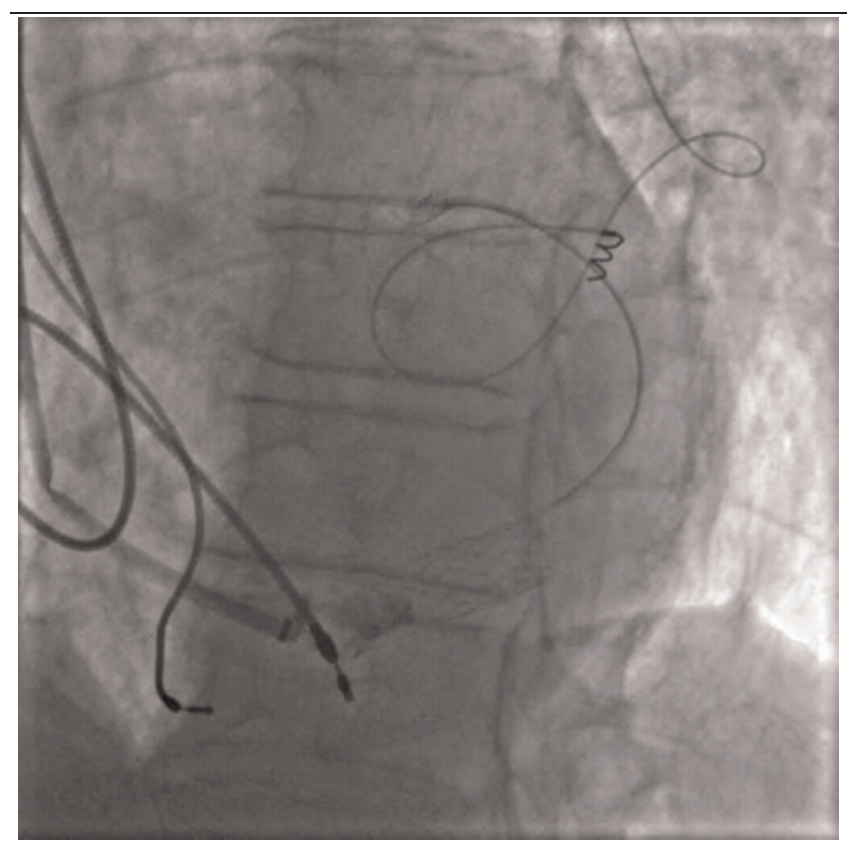

A left anterior oblique view of a clinical case of coronary sinus prosthetic percutaneous annuloplasty is shown. The device is positioned in the coronary sinus. A proximal stent is deployed in the proximal part of the coronary sinus, and the distal stent is deployed in the distal part of the coronary sinus. A constraining bridge connects the two stents. 
The preliminary results obtained in around 200 patients with functional MR suggest that the feasibility ranges from $40 \%$ to $80 \%$ and that safety is satisfactory ( $83 \%$ of implanted patients are event-free at 90 days). After 2 years, preliminary studies show that $80 \%$ of the patients survive and most of them experience functional improvement. Data on efficacy are more limited and show a trend toward reduction of the degree of MR. In addition, up to $30 \%$ of patients had some degree of circumflex cinching, but this led to adverse events in only a few cases [19-21].

The coronary sinus approach also has potential limitations. The long-term benefits of mitral valve repair in functional MR are debated [22]. The ring inserted into the coronary sinus is localised to the posterior half of the annulus, where surgeons usually use undersized and complete rings [23]. The coronary sinus is 1 or $2 \mathrm{~cm}$ away from the atrioventricular groove on the atrial side, and this may also decrease the efficacy [24]. Finally, there is a potential risk of cinching the circumflex artery whilst crossing the coronary sinus $[25,26]$. This requires noninvasive anatomic evaluation before the procedure by using computed tomography imaging $[25,26]$.

Several other devices and techniques are currently being investigated experimentally or tested in humans for the first time: 'direct' annuloplasty (such as transventricular suture-based annuloplasty or subannular annuloplasty), and 'mitral cerclage' annuloplasty, in which ventricular remodelling using either transpericardial ventricular remodelling with anchoring pads on either side of the ventricle or a combination of anchors placed in the coronary sinus and the atrial septum allows a tensioning cable to be placed across the left atrium, applying tension to reduce the septal lateral dimension. Finally, the first experiments on percutaneous valve replacement have also been performed.

\section{Implications for clinical practice}

The data we have on these new techniques are still limited and suffer from a number of methodological limitations. A lot of questions are still pending: more clinical data are needed to accurately assess efficacy, safety, and durability. The EVEREST II randomised study comparing the percutaneous edge-to-edge technique with surgery will be presented soon and further safety and efficacy studies are to be conducted with percutaneous annuloplasty. It is essential to know whether secondary intervention, either percutaneous (including resynchronisation) or surgical, will be feasible. Imaging guidance using three-dimensional transoesophageal echocardiography will improve the performance of the edge-to-edge technique. Overall, it is unlikely that these new percutaneous techniques will reproduce the current results of surgical valve repair; however, they may play a role in patients with contraindications to or high risk for surgery. This concerns a large population and may have a great clinical impact [27].

\section{Abbreviations}

EVEREST, Endovascular Valve Edge-to-Edge Repair Study; MR, mitral regurgitation.

\section{Competing interests}

The authors declare that they have no competing interests.

\section{References}

I. Enriquez-Sarano M, Akins CW, Vahanian A: Mitral regurgitation. Lancet 2009, 373:1382-94.

2. Nkomo VT, Gardin JM, Skelton TN, Gottdiener JS, Scott CG, Enriquez-Sarano M: Burden of valvular heart diseases: a population-based study. Lancet 2006, 368:I005-II.

fl000 Factor 3.0 Recommended

Evaluated by Wilbert Aronow 23 Oct 2006

3. lung B, Baron G, Butchart EG, Delahaye F, Gohlke-Bärwolf C, Levang OW, Tornos P, Vanoverschelde JL, Vermeer F, Boersma E, Ravaud $P$, Vahanian A: A prospective survey of patients with valvular heart disease in Europe: The Euro Heart Survey on Valvular Heart Disease. Eur Heart J 2003, 24: I23 I-43.

4. Vahanian A, Baumgartner H, Bax J, Butchart E, Dion R, Filippatos G, Flachskampf F, Hall R, lung B, Kasprzak J, Nataf P, Tornos P, Torracca L, Wenink A; Task Force on the Management of Valvular Hearth Disease of the European Society of Cardiology; ESC Committee for Practice Guidelines: Guidelines on the management of valvular heart disease: The Task Force on the Management of Valvular Heart Disease of the European Society of Cardiology. Eur Heart J 2007, 28:230-68.

Changes Clinical Practice

fl000 Factor 9.0 Exceptional

Evaluated by Raimund Erbel 10 May 2007

5. Bonow RO, Carabello BA, Chatterjee K, de Leon AC Jr, Faxon DP, Freed MD, Gaasch WH, Lytle BW, Nishimura RA, O'Gara PT, O'Rourke RA, Otto CM, Shah PM, Shanewise JS, Smith SC Jr, Jacobs AK, Adams CD, Anderson JL, Antman EM, Faxon DP, Fuster V, Halperin JL, Hiratzka LF, Hunt SA, Lytle BW, Nishimura R, Page RL, Riegel B: ACCIAHA 2006 guidelines for the management of patients with valvular heart disease: a report of the American College of Cardiology/American Heart Association Task Force on Practice Guidelines (writing Committee to Revise the 1998 guidelines for the management of patients with valvular heart disease) developed in collaboration with the Society of Cardiovascular Anesthesiologists endorsed by the Society for Cardiovascular Angiography and Interventions and the Society of Thoracic Surgeons. J Am Coll Cardiol 2006, 48: el-el48.

6. Gillinov AM, Blackstone EH, Nowicki ER, Slisatkorn W, Al-Dossari G, Johnston DR, George KM, Houghtaling PL, Griffin B, Sabik JF III, Svensson LG: Valve repair versus valve replacement for degenerative mitral valve disease. J Thorac Cardiovasc Surg 2008, I35:885-93.

7. Mirabel M, lung B, Baron G, Messika-Zeitoun D, Détaint D, Vanoverschelde JL, Butchart EG, Ravaud P, Vahanian A: What are the characteristics of patients with severe, symptomatic, 
mitral regurgitation who are denied surgery? Eur Heart J 2007, 28:1358-65.

fl000 Factor 3.0 Recommended

Evaluated by Elliot Rapaport 06 Sep 2007

8. Gillinov AM, Blackstone EH, Rajeswaran J, Mawad M, McCarthy PM, Sabik JF III, Shiota T, Lytle BW, Cosgrove DM: Ischemic versus degenerative mitral regurgitation: does etiology affect survival? Ann Thorac Surg 2005, 80:8II-9.

9. Gammie JS, O'Brien SM, Griffith BP, Ferguson TB, Peterson ED: Influence of hospital procedural volume on care process and mortality for patients undergoing elective surgery for mitral regurgitation. Circulation 2007, I I 5:88I-7.

10. Alfieri O, Maisano F, De Bonis M, Stefano PL, Torracca L, Oppizzi M, La Canna G: The double-orifice technique in mitral valve repair: a simple solution for complex problems. J Thorac Cardiovasc Surg 200I, I 22:674-8I.

II. St Goar FG, Fann JI, Komtebedde J, Foster E, Oz MC, Fogarty TJ, Feldman T, Block PC: Endovascular edge-to-edge mitral valve repair: short-term results in a porcine model. Circulation 2003, 108:1990-3.

12. Silvestry FE, Rodriguez LL, Herrmann HC, Rohatgi S, Weiss SJ, Stewart WJ, Homma S, Goyal N, Pulerwitz T, Zunamon A, Hamilton A, Merlino J, Martin R, Krabill K, Block PC, Whitlow P, Tuzcu EM, Kapadia S, Gray WA, Reisman M, Wasserman H, Schwartz A, Foster E, Feldman T, Wiegers SE: Echocardiographic guidance and assessment of percutaneous repair for mitral regurgitation with the Evalve MitraClip: lessons learned from EVEREST I. J Am Soc Echocardiogr 2007, 20: I I3।-40.

13. Feldman T, Wasserman HS, Herrmann HC, Gray W, Block PC, Whitlow P, St Goar F, Rodriguez L, Silvestry F, Schwartz A, Sanborn TA, Condado JA, Foster E: Percutaneous mitral valve repair using the edge-to-edge technique: six-month results of the EVEREST Phase I Clinical Trial. J Am Coll Cardiol 2005, 46:2134-40

14. Feldman T, Kar S, Rinaldi M, Fail P, Hermiller J, Smalling R, Whitlow PL, Gray W, Low R, Herrmann HC, Lim S, Foster E, Glower D; EVEREST Investigators: Percutaneous mitral repair with the MitraClip system: safety and midterm durability in the initial EVEREST (Endovascular Valve Edge-to-Edge REpair Study) cohort. J Am Coll Cardiol 2009, 54:686-94.

15. Webb JG, Maisano F, Vahanian A, Munt B, Naqvi TZ, Bonan R, Zarbatany D, Buchbinder M: Percutaneous suture edge-to-edge repair of the mitral valve. Eurointervention 2009, 5:86-9.

16. Foster E, Wasserman HS, Gray W, Homma S, Di Tullio MR, Rodriguez L, Stewart WJ, Whitlow P, Block P, Martin R, Merlino J, Herrmann HC, Wiegers SE, Silvestry FE, Hamilton A, Zunamon A, Kraybill K, Gerber IL, Weeks SG, Zhang Y, Feldman T: Quantitative assessment of severity of mitral regurgitation by serial echocardiography in a multicenter clinical trial of percutaneous mitral valve repair. Am J Cardiol 2007, I00:1577-83.

17. Herrmann HC, Kar S, Siegel R, Fail P, Loghin C, Lim S, Hahn R, Rogers JH, Bommer WJ, Wang A, Berke A, Lerakis S, Kramer P, Wong SC, Foster E, Glower D, Feldman T; EVEREST Investigators: Effect of percutaneous mitral repair with the MitraClip device on mitral valve area and gradient. Eurolntervention 2009, 4:437-42.

18. Byrne MJ, Kaye DM, Mathis M, Reuter DG, Alferness CA, Power JM: Percutaneous mitral annular reduction provides continued benefit in an ovine model of dilated cardiomyopathy. Circulation 2004, I 10:3088-92.

19. Schoffer J, Siminiak T, Haude M, Herrman JP, Vainer J, Wu JC, Levy WC, Mauri L, Feldman T, Kwong RY, Kaye DM, Duffy SJ, Tübler T, Degen H, Brandt MC, Van Bibber R, Goldberg S, Reuter DG, Hoppe UC: Percutaneous mitral annuloplasty for functional mitral regurgitation: results of the CARILLON mitral annuloplasty device European Union study. Circulation 2009, I 20:326-33.

20. Sack $S$, Kahlert $P$, Bilodeau L, Pièrard LA, Lancellotti $P$, Legrand $V$, Bartunek J, Vanderheyden M, Hoffmann R, Schauerte E, Shiota T, Marks DS, Erbel R, Ellis SG: Percutaneous transvenous mitral annuloplasty: initial human experience with a novel coronary sinus implant device. Circ Cardiovasc Intervent 2009, 2:277-84.

21. Webb JG, Harnek J, Munt BI, Kimblad PO, Chandavimol M, Thompson CR, Mayo JR, Solem JO: Percutaneous transvenous mitral annuloplasty: initial human experience with device implantation in the coronary sinus. Circulation 2006, I 13:85 I-5.

22. Wu AH, Aaronson KD, Bolling SF, Pagani FD, Welch K, Koelling TM: Impact of mitral valve annuloplasty on mortality risk in patients with mitral regurgitation and left ventricular systolic dysfunction. J Am Coll Cardiol 2005, 45:38I-7.

23. Bax JJ, Braun J, Somer ST, Klautz R, Holman ER, Versteegh MI, Boersma E, Schalij MJ, van der Wall EE, Dion RA: Restrictive annuloplasty and coronary revascularization in ischemic mitral regurgitation results in reverse left ventricular remodeling. Circulation 2004, I I0(II Suppl I): III 03-8.

24. Maselli D, Guarracino F, Chiaramonti F, Mangia F, Borelli G, Minzioni G: Percutaneous mitral annuloplasty: an anatomic study of human coronary sinus and its relation with mitral valve annulus and coronary arteries. Circulation 2006, II4 $377-80$

25. Choure AJ, Garcia MJ, Hesse B, Sevensma M, Maly G Greenberg NL, Borzi L, Ellis S, Tuzcu M, Kapadia SR: In vivo analysis of the anatomical relationship of coronary sinus to mitral annulus and left circumflex coronary artery using cardiac multidetector computed tomography implications for percutaneous coronary sinus mitral annuloplasty. J Am Coll Cardiol 2006, 48: $1938-45$.

26. Tops LF, Van de Veire NR, Schuijf JD, de Roos A, van der Wall EE, Schalij MJ, Bax JJ: Noninvasive evaluation of coronary sinus anatomy and its relation to the mitral annulus: implications for percutaneous mitral annuloplasty. Circulation 2007, I I 5: 1426-32.

27. Rosengart TK, Feldman T, Borger MA, Vassiliades TA Jr., Gillinov AM, Hoercher KJ, Vahanian A, Bonow RO, O'Neill W; American Heart Association Council on Cardiovascular Surgery and Anesthesia; American Heart Association Council on Clinical Cardiology Functional Genomics and Translational Biology Interdisciplinary Working GroupQuality of Care and Outcomes Research Interdisciplinary Working Group: Percutaneous and minimally invasive valve procedures: a scientific statement from the American Heart Association Council on Cardiovascular Surgery and Anesthesia, Council on Clinical Cardiology, Functional Genomics and Translational Biology Interdisciplinary Working Group, and Quality of Care and Outcomes Research Interdisciplinary Working Group. Circulation 2008, I I 7:1750-67. 